\title{
Occupational exposure and poisoning by chemical products in the Federal District
}

\author{
Exposição e intoxicação ocupacional a produtos químicos no Distrito Federal \\ Exposición e intoxicación ocupacional a productos químicos en el Distrito Federal
}

Andrea Franco Amoras Magalhães'

ORCID: 0000-0002-8232-8995

Eloisa Dutra Caldas"

ORCID: 0000-0002-7197-6807

'Secretaria de Saúde do Governo do Distrito Federal. Brasília, Distrito Federal, Brazil.

"Universidade de Brasília, Department of Pharmacy.

Brasília, Distrito Federal, Brazil.

How to cite this article:

Magalhães AFA, Caldas ED. Occupational exposure and poisoning by chemical products in the Federal District.

Rev Bras Enferm [Internet]. 2019;72(Suppl 1):32-40.

[Thematic Issue: Work and Management in Nursing].

DOI: http://dx.doi.org/10.1590/0034-7167-2017-0439

\section{Corresponding Author: \\ Eloisa Dutra Caldas \\ E-mail: eloisa@unb.br}

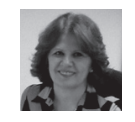

Submission: 06-20-2017

Approval: 01-27-2018

\section{ABSTRACT}

Objective: to describe case of occupational exposure to chemical products. Method: descriptive retrospective study using record data of 382 workers assisted in the Outpatient Care for Occupational Toxicology of the Reference Center of Workers' Health of the Federal District, between 2009 and 2013. Results: From the total, 66.7\% were men, $55.2 \%$ had up to 9 years of activity and $81 \%$ did not use personal protective equipment (PPE). Nearly $60 \%$ were farmers and environmental surveillance agents, exposed to pesticides (63\%), of which $40 \%$ were organophosphorus insecticides. The majority (68\%) presented butyrylcholinesterase activity decreased, mostly farmers (85.9\%); $57.3 \%$ of workers were considered poisoned $-61.6 \%$ by pesticides and $37.9 \%$ by industrial chemicals -, and away from work for at least 10 days. Conclusion: The profile was male workers, from 30 to 39 years, which not used PPE, indicating the need for prevention together with them to prevent poisonings.

Descriptors: Occupational Health; Chemical Compounds; Poisoning; Pesticides; Outpatient Care.

\section{RESUMO}

Objetivo: descrever casos de exposição ocupacional a produtos químicos. Método: estudo retrospectivo descritivo utilizando dados do prontuário de 382 trabalhadores atendidos no Ambulatório de Toxicologia Ocupacional do Centro de Referência em Saúde do Trabalhador do Distrito Federal, entre 2009 e 2013. Resultados: 66,7\% eram homens, $55,2 \%$ tinham até 9 anos de atividade e $81 \%$ não usavam equipamento de proteção individual (EPI). Quase $60 \%$ eram agricultores e agentes de vigilância ambiental, expostos a agrotóxicos (63\%), dos quais $40 \%$ inseticidas organofosforados. A maioria $(68 \%)$ apresentou atividade de butirilcolinesterase diminuída, principalmente agricultores (85,9\%); 57,3\% dos trabalhadores foram considerados intoxicados, $61,6 \%$ por agrotóxicos e $37,9 \%$ por produtos químicos industriais, e afastados do trabalho por pelo menos 10 dias. Conclusão: O perfil dos trabalhadores atendidos foi de homens, predominantemente de 30 a 39 anos, que não utilizavam EPI, indicando a necessidade de ações de prevenção junto a essa população para evitar a ocorrência de intoxicações. Descritores: Saúde do Trabalhador; Compostos Químicos; Envenenamento; Agrotóxicos; Assistência Ambulatorial.

\section{RESUMEN}

Objetivo: describir casos de exposición ocupacional a productos químicos. Método: estudio retrospectivo descriptivo utilizando datos del prontuario de 382 trabajadores atendidos en el Ambulatorio de Toxicología Ocupacional del Centro de Referencia en Salud del Trabajador del Distrito Federal entre 2009 y 2013. Resultados: El 66,7\% eran hombres, el 55,2\% tenía hasta 9 años de actividad y el $81 \%$ no usaba el equipo de protección individual (EPI).Casiel60\% eran agricultoresyagentes de vigilanciaambiental, expuestos a agrotóxicos (63\%), de los cuales $40 \%$ insecticidas organofosforados. La mayoría (68\%) presentó actividad de butirilcolinesterasa disminuida, principalmente agricultores (85,9\%); el $57,3 \%$ de los trabajadores fueron considerados intoxicados, $61,6 \%$ por agrotóxicos y $37,9 \%$ por productos químicos industriales, y alejados del trabajo por lo menos 10 días. Conclusión: El perfil de los trabajadores atendidos fue de hombres, predominantemente de 30 a 39 años, que no utilizaban el EPI, indicando la necesidad de acciones de prevención junto a esa población para evitar la ocurrencia de intoxicaciones.

Descriptores: Salud del Trabajador; Compuestos Químicos; Envenenamiento; Agrotóxicos; Asistencia Ambulatoria. 


\section{INTRODUCTION}

Since the primordium, the man lives with various toxic agents of chemical and biological origin, including those ubiquitous in nature, such as bacteria and heavy metals. From the industrial revolution and the modernization of agricultural activity, new agents were inserted in society with a potential risk to human health, including pesticides and products used in industry ${ }^{(1)}$. Workers involved with these agents in the work activity constitute the population in a more critical situation, since the level of exposure is greater compared to the general population and, consequently, the greater are the risks of damages to health ${ }^{(2)}$.

According to the National Poison Information System (SINITOX), which compiles data from human poisoning recorded by toxicological information centers (TIC), $72.3 \%$ of occurrences reported between 2009 and 2013 were individual accidents and suicide attempt, and $5.8 \%$ of occupational cause ${ }^{(3)}$. Data from the TIC of the Federal District indicates that 3.5\% of the poisonings during the same period were occupational, but the Brazil Information System for Notifiable Diseases (SINAN) reported that this percentage is $6 \%{ }^{(4)}$. Sousa and Santana ${ }^{(5)}$ identified that $2.3 \%$ of the 8,923 occupational injuries that occurred in Brazil between 2000 and 2010 were due to pesticides poisoning.

Pesticides poisoning is a major problem of Public health service, especially in developed and developing countries ${ }^{(6-7)}$. Since 2008, Brazil is among the three largest users of pesticides in the world, with more than 500 thousand tons of products in the country market in $2014^{(8)}$. Occupational exposure to pesticides occurs mainly in the field, but it also is significant in urban environments in vector control and the domestic debugging. Among the industrial products more poisoning for humans are mainly the halogenated solvents, used in paint removers ${ }^{(2)}$. The metal poisoning is widely described in the literature, especially with lead, the most abundant toxic metal in nature and with many industrial use $\mathrm{e}^{(1-2)}$.

In Brazil, the main strategy of health care for workers in the Unified Health System (SUS) is the National Network for Workers' Health Care (RENAST), established by the Ordinance GM No $1679 / 2002$ to articulate the institutions of the services network of the System. In this context, Reference Center for workers' health (CERESTs) were created, whose duties are to coordinate worker's health actions and to be a reference in medical specialties for work-related diseases. Their competencies are part of the guidelines of the National Policy on Worker's Health ${ }^{(9)}$. The Outpatient Care for Occupational Toxicology of the CEREST of the Federal District was created in 2003 in partnership with the CIT of the Federal District, supported by the Central Public Health Laboratory (LACEN) of the Health Office of the Federal District. The assignments, are to identify and control the health risk factors present in working environments and conditions in order to propose treatment and prevention of work-related damage, injuries or illnesses, based on a diagnosis ${ }^{(4)}$.

\section{OBJECTIVE}

Describe the cases of poisoning by chemical products attended at the Outpatient Care for Occupational Toxicology of the
CEREST of the Federal District between 2009 and 2013. The study is relevant due to the scarcity of outpatient care data of patients occupationally exposed to chemical products in the country.

\section{METHOD}

\section{Ethical aspects}

It was used a secondary database with assured confidentiality and anonymity of the patients, in accordance with Resolution $466 / 2012$ of the National Council of Health. The study was approved by the Research Ethics Committees of the Foundation Support Research of the Federal District.

\section{Design, study location and period}

Descriptive retrospective study, which had as primary source the medical record of patients assisted in the Outpatient Care for Occupational Toxicology of the CEREST of the Federal District, between January $1^{\text {st }}$ of 2009 to December 31 st of 2013. The Federal District area is $5.780 \mathrm{Km}^{2}$ and, in 2010 , had a population of $2,570,160$ individuals, mainly involved in the service sector $(93 \%$ of economic activities). The industrial and agricultural activities contributed to $6.5 \%$ and $0.3 \%$, respectively ${ }^{(10)}$. The CEREST of the Federal District covers all the District area, but can also reach the surrounding cities, belonging to the States of Goiás, Minas Gerais and Bahia ${ }^{(4)}$.

\section{Population of the study}

The criteria for inclusion in the study were patients (men and women) residing in the Federal District, with occupational exposure to chemicals, aged 18 years or more, of which the first assistance was provided from January 1st of 2009 to December 31st of 2013. Were excluded all residents under 18 years old and not residents in the Federal District. The study only counted the first visit, not considering the return visits in the total number of cases.

\section{Data source and Variables}

The information obtained from the medical records of patients were: date of the first service, patient identification (sex, age, education and occupation), time and route of exposure, toxic agent (class, trade name and active ingredient), use of personal protective equipment (PPE), clinical signs and symptoms reported and observed in the clinical examination, laboratory tests, final diagnosis and evolution of the case. The final diagnosis was based on criteria of occupational exposure, clinical and laboratory/ toxicology.

According to the assistance protocol into force in the CEREST of the Federal District during the study, the laboratory tests included blood tests to check the bone marrow function, AST (Aspartate Transaminase); ALT (Alanine Transaminase) to assess liver function; urea and creatinine to assess kidney function, and assessment of thyroid function (T3, T4 and TSH). Abdominal scan and chest $x$-ray also were requested. All tests should be made within 90 days after the request. 
Butyrylcholinesterase enzyme (BChE) analysis, an indicator of the effect of organophosphorus insecticides and carbamates, was held in workers exposed to pesticides using commercial kit DiaSys (Diagnostic Systems GmbH), which indicates values of reference for women (3930 to $10800 \mathrm{U} / \mathrm{L}$ ) and for men (4620 to $11500 \mathrm{U} / \mathrm{L}$ ). The dosage that have enzymatic activity below the lower reference range of the kit were considered changed.

The Communication of Work Accident (CAT) was fulfilled for intoxicated workers governed by the Brazilian Labor Code (CLT), or provided medical report to the agency of origin of civil servants. When necessary, the evaluated workers were referred to the medical specialties within the healthcare system of the Public Health Network of the Federal District for investigation and treatment of specific pathologies. All cases were notified to SINAN.

\section{Analysis of results}

Data from the medical records were transferred to the Software SPSS V. 20 (SPSS Inc., Chicago, United States) for descriptive analysis.

\section{RESULTS}

The study included 382 workers residing in the Federal District occupationally exposed to chemical products, attended at the Outpatient Care for Occupational Toxicology of the CEREST of the Federal District, from 2009 to 2013, for clinical-toxicological evaluation. All workers were referred by the Public Health Network of the Federal District. The number of attendances decreased dramatically over the period: from 93 cases, in 2009, to 50, in 2013. Table 1 shows the characteristics of the workers of the outpatient care.

Table 1 - Characteristic of workers of the Outpatient Care for Occupational Toxicology of the Reference Center for Workers' Health of the Federal District between 2009 to 2013, in Brasília, Federal District, Brazil

\begin{tabular}{lcc}
\hline Parameter & $\mathbf{n}$ & $\%$ \\
\hline Gender & & \\
Male & 255 & 66.7 \\
$\quad$ Female & 127 & 33.3 \\
Age (years) & & \\
18 to 29 & 56 & 14.7 \\
30 to 39 & 109 & 28.5 \\
40 to 49 & 95 & 24.7 \\
50 to 59 & 93 & 24.3 \\
60 or more & 29 & 7.6 \\
Education & & \\
Without education & 2 & 0.5 \\
Elementary Education & 173 & 45.3 \\
Secondary Education & 177 & 46.3 \\
Incomplete Higher Education & 8 & 2.1 \\
Full Higher Education & 22 & 5.8 \\
Exposure Time & & \\
Up to 24h & 25 & 6.5 \\
>24h. 4 years & 111 & 29.1 \\
5-9 years & 100 & 26.2 \\
10-14 years & 44 & 11.5 \\
15-19 years & 36 & 9.4 \\
20-30 years & 42 & 11 \\
Over 30 years & 23 & 6 \\
\hline
\end{tabular}

Most of the workers were male, accounting for more than $80 \%$ of the cases in $2009 ; 28.5 \%$ were between 30 and 39 years old, and $7.6 \%$ of them were over 60 years old. Almost half of the workers (45.3\%) studied until elementary education (Table 1). While $46.5 \%$ of farmers had only elementary education, most of the environmental monitoring agents (87.0\%) had secondary education. The majority of those attended worked in their occupation for up to 9 years, and $6.5 \%$ were attended due to an acute condition with up to 24 hours of exposure (Table 1).

Most of the attended cases involved exposure to pesticides, followed by industrial chemicals (Table 2). Nearly $60 \%$ of the visits were from farmers and environmental monitoring agents (EMA), who are employees of the Health Office of the Federal District and endemic diseases agents of the former Superintendence of Public Health Campaigns, now the National Health Foundation, which carry out activities to combat disease vectors

The third occupational activity more frequent was the cleaning assistant/one-day cleaner, which involved mostly women (Table 2). No woman attended belonged to the group of painter/automotive mechanic, metallurgical technician and mason, which reflects the predominance of men in these activities. The cleaning assistant/oneday cleaner was exposed mainly to sanitizers (26 cases), with products containing mainly sodium hypochlorite, caustic soda and ammonia. The multiple occupational exposure to products of various classes was present in 48 workers ( $12.5 \%$ of the total), mainly industrial chemicals and metals (77.0\%), followed by raticides and pesticides used in public health campaigns (10.4\%). In all cases of exposure to metals and raticides, there was co-exposure to another chemical agent (Table 2).

The main routes of exposure of workers were cutaneous and respiratory ( $87.2 \%$ of the cases). The majority ( $81.7 \%)$ reported not using any type of personal protective equipment (PPE) $(73.0 \%$ among environmental monitoring agents and $78.7 \%$ among farmers). Among workers who used some PPE $(\mathrm{N}=70)$, gloves and masks were the most used (32.8\%), and only $1.4 \%$ reported the use of complete PPE (boot, hat, apron or waterproof clothing, glove, mask and glasses). Workers exposed to pesticides were involved in various activities, including loading, unloading and marketing of products, preparation and application (agricultural and live stock farming activities, public health campaigns and debugging) and maintenance of green areas and gardens. All reported exposure to more than one pesticide product, but $23.6 \%$ of them did not identify the chemical group or the name of the product involved.

Among the 184 cases with exposure to pesticides with identified chemical group, more than half ( 96 cases) had contact with organophosphate insecticides, mainly temephos by environmental monitoring agents, and methamidophos by farmers (Table 3). Twenty-one cases involved pyrethroid insecticides, of which 17 with deltamethrin, single (12) or associated with glyphosate (5), which was involved in another 22 cases, 19 of which with farmworkers. The insecticide diflubenzuron was involved in 9 cases with monitoring agents (Table 3 ). Other pesticides include the insecticide chlorfenapyr ( 5 cases) and the herbicide paraquate ( 3 cases), as well as 15 other pesticides of different classes.

Among the workers exposed to pesticides, 53.1\% did BChE analysis, of which 71 were farmers and 51 environmental monitoring agents (Table 3 ). The majority presented decreased $\mathrm{BChE}$ results, mainly farmers (85.9\%). 
Table 2 - Workers of the Outpatient Care for Occupational Toxicology of the Reference Center for Workers' Health of the Federal District between 2009 to 2013, according to occupation and toxic agent involved during exposure, in Brasília, Federal District, Brazil

\begin{tabular}{|c|c|c|c|c|c|c|c|}
\hline Occupation & $\begin{array}{l}\text { Total } \\
\text { n (\%) }\end{array}$ & $\begin{array}{c}\text { Male } \\
\%\end{array}$ & $\begin{array}{c}\text { Pesticides } \\
\text { n }\end{array}$ & $\begin{array}{c}\text { ICQ } \\
\text { n }\end{array}$ & $\begin{array}{c}\text { Metals } \\
\mathrm{n}\end{array}$ & $\begin{array}{c}\text { Sanitizers } \\
\mathbf{n}\end{array}$ & $\begin{array}{c}\text { Raticides } \\
\mathbf{n}\end{array}$ \\
\hline Farmer ${ }^{1}$ & $113(29.6)$ & 92.9 & 113 & - & 1 & - & - \\
\hline Environmental monitoring agent ${ }^{2}$ & $108(28.3)$ & 57.4 & 106 & - & - & - & 7 \\
\hline Cleaning assistant/One-day Cleaner & $36(9.4)$ & 33.3 & 5 & 2 & 2 & 26 & 1 \\
\hline Painter/automotive mechanic & $15(3.9)$ & 100 & - & 15 & 13 & - & - \\
\hline Metallurgical technician & $13(3.4)$ & 100 & - & 8 & 8 & - & - \\
\hline Civil servant $^{3}$ & $10(2.6)$ & 20 & 5 & 5 & 3 & - & - \\
\hline Gas station attendant & $7(1.8)$ & 57.1 & - & 7 & - & - & - \\
\hline Laboratory Technician & $7(1.8)$ & 71.4 & 1 & 6 & 1 & - & - \\
\hline Mason & $6(1.6)$ & 100 & - & 5 & 1 & - & - \\
\hline Others ${ }^{4}$ & $67(17.5)$ & 46.3 & 11 & 46 & 26 & - & 2 \\
\hline Total & $382(100)$ & 255 (66.7) & $241(63.1)$ & $94(24.6)$ & $56(14.6)$ & $26(6.8)$ & $10(2.6)$ \\
\hline
\end{tabular}

Note: $N=$ number of workers \% in relation to the total of the occupational group; ICQ: industrial chemical products; 'includes 2 farmer tractor drivers e 1 agricultural technician; ${ }^{2}$ includes 8 environmental monitoring drivers; ${ }^{3}$ poisoned in the work environment; ${ }^{4}$ includes debugging company worker, groundsman, bus driver, gold miner, serigrapher, among others.

Table 3 - Main pesticides, occupation and BChE test results in the cases of the Outpatient Care for Occupational Toxicology of the Reference Center for Workers' Health of the Federal District from 2009 to 2013, in Brasília, Federal District, Brazil

\begin{tabular}{lc}
\hline Pesticides & \multicolumn{1}{c}{ Cases, $\mathbf{n}$ (occupation) } \\
\hline Temephos & 80 (79 monitoring agents) \\
Methamidophos & 12 (11 farmers) \\
Pyrethroids & 21 (15 farmers, 5 monitoring agents) \\
Glyphosate & 27 (19 farmers) \\
Diflubenzuron & 9 (monitoring agents) \\
\hline Occupation & BChE carried out, $\mathbf{n}$ (\% decreased) \\
\hline Farmer & $71(85.9)$ \\
Environmental monitoring agent & $51(43.1)$ \\
Others & $6(66.7)$ \\
\hline
\end{tabular}

The poisoned monitoring agents and farmworkers reported several signs and symptoms at the visit, mainly headache, blurred vision, pruritus and nausea (Figure 2). Dyspnea, hacking cough, watery eyes and ocular hyperemia were the most highlighted symptoms among farmworkers.

Among the 135 workers considered poisoned by pesticides, it was found that the number of red blood cells had declined in $9.5 \%$ of the 115 available results; hemoglobin in $3.9 \%$ of the 101 available results; leukocytes in $4.5 \%$ of the 115 available results (leukopenia); and platelets changed in 1 of the 94 available results (thrombocytopenia). Among the 89 results reported for ALT and AST, 4.4\% and $5.5 \%$, respectively, were changed, and all were from environmental monitoring agents. Of the 109 patients with abdominal scan results, 7 showed altered results, being 2 public health workers and 2 farmworkers, indicating liver changes, confirmed by altered AST and ALT. All 77 workers that performed chest x-ray showed no abnormalities.

Industrial chemicals were involved in 75 poisoning (mainly solvents), associated or not with metals (Figure 1), mainly lead. These workers reported mainly neurological symptoms (64\%, mainly headache and irritability) and dermatological (62.7\%, mainly dermatitis and pruritus). Arterial hypertension, dyspnea, and headache were reported by $75 \%$ of the 8 workers exposed to metals. All the employees were submitted to a blood test, and 11 of them had thrombocytopenia and leukopenia; no changes were found in other laboratory parameters.
Despite having been requested routine laboratory tests (blood and urine), chest x-ray and abdominal scan for all 382 workers assisted at the Outpatient Care, in the vast majority of cases (93.7\%) at least 1 requested test was not carried out, mainly due to the inability of the health system to meet this request no later than 90 days after the first visit.

Of the 382 workers assisted, $57.3 \%$ were considered poisoned by the agent to which they were exposed, mainly by pesticides (Figure 1), corresponding to $61.6 \%$ of the total poisoned and $56.0 \%$ of those exposed to pesticides. In total, 47 cases involved poisoning with organophosphate insecticides, 17 with glyphosate and 9 with pyrethroids. The 74 farmworkers were poisoned mainly by glyphosate and methamidophos, but 35 cases (47.3\%) did not have the agent identified (Figure 1). The 48 environmental monitoring agents were poisoned mainly with the temephos (35 cases; Figure 1), of which $62.8 \%$ presented BChE changed. Industrial chemicals were involved in 75 poisoning, 43 as a single agent (mainly halogenated solvents) and 32 associated with metals (Figure 1), mainly lead.

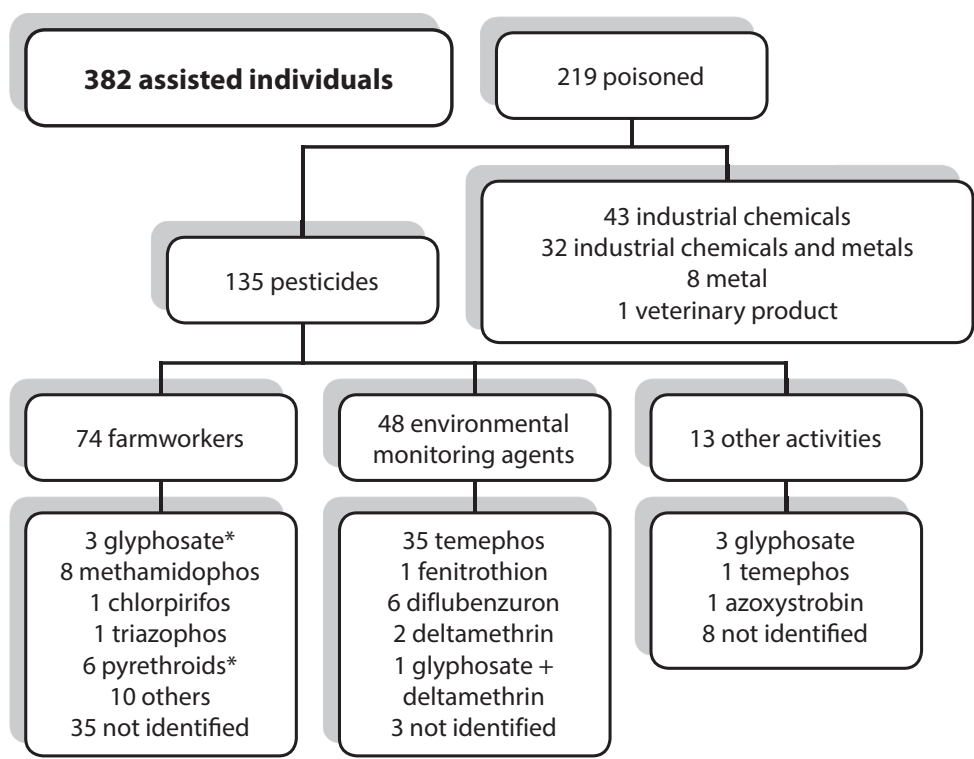

Note- * 1 case of poisoning with glyphosate + deltamethrin

Figure 1 - Cases of occupational exposure and poisoning assisted at the Outpatient Care for Occupational Toxicology of the Reference Center for Workers' Health of the Federal District from 2009 to 2013 


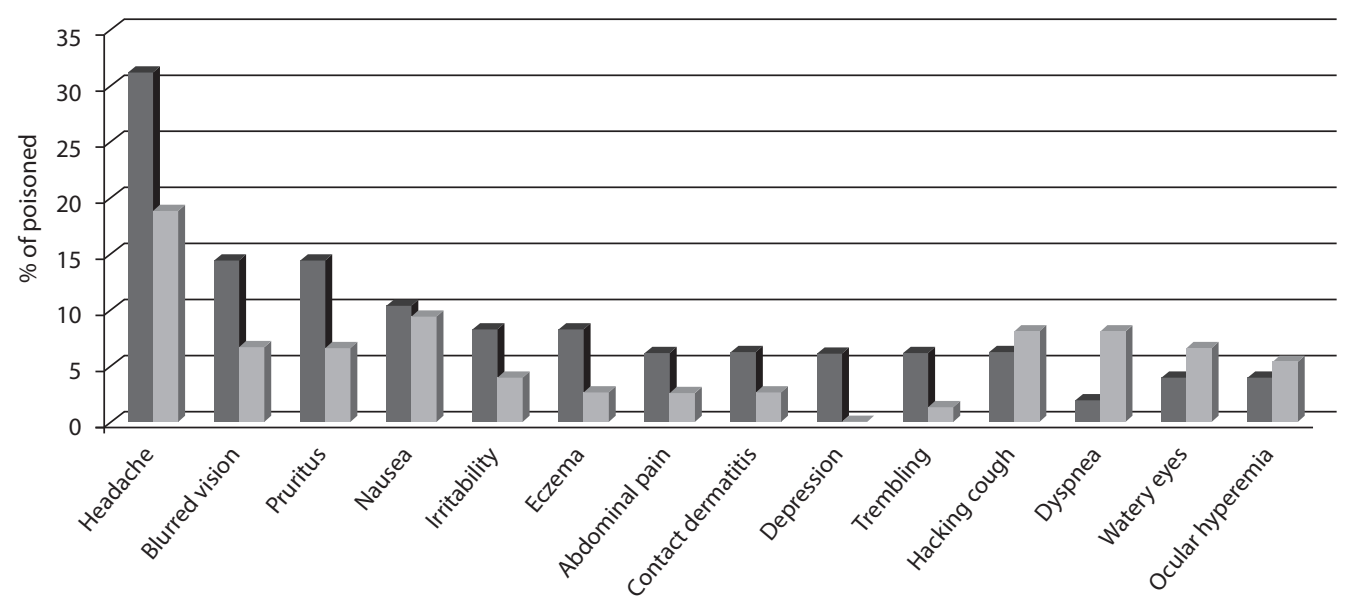

Environmental monitoring agent, $\mathrm{N}=48 \quad$ Farmworker, $\mathrm{N}=74$

Figure 2 - Main symptoms related to exposure and poisoning reported by poisoned environmental monitoring agents and farmworkers assisted at the Outpatient Care for Occupational Toxicology of the Reference Center for Workers' Health of the Federal District from 2009 to 2013

The average length of sick leave granted to poisoned workers was 60 days, with extremes of 10 days and 120 days, depending on the need of each case. The workers with decreased BChE, only returned to work after normalization of the enzyme levels. No death occurred among patients seen at the Outpatient Care during the study period.

\section{DISCUSSION}

In the period of the study (2009-2013), the Outpatient Care of the CEREST of the Federal District assisted 382 new patients, with an average of 6.3 visits per month, lower than the average number of outpatient visits observed in a previous study between April of 2003 and July of 2005 (222 visits, 8 per month) ${ }^{(11)}$. This drop was expected, whereas over the years the Outpatient Care was being established as reference of specialty, assisting only the patients referred from the public healthcare network of the Federal District. Until 2007/2008 the patients arrived at the Outpatient Care also by notification from the Monitoring Management in Health for Workers to the employer, after inspection on environment with chemical risk, or by spontaneous demand. These two segments accounted for $28.4 \%$ of the visits assisted by the Outpatient Care between 2003 and $2005^{(10)}$. Another factor which contributed to the number of visits was the creation of the VIGITOX Project by the CEREST, where the visits are carried out by the team of the outpatient care, directly in the countryside along with the Family Health Unit, focusing on the farmer. These visits are not included in the study, because the medical records of farmers are in units of the Family Health.

Nearly $60 \%$ of the visits were farmers and environmental monitoring agents, exposed mainly to pesticides. This profile is different from that observed in the previous study ${ }^{(11)}$, in which about $71 \%$ of the visits in the Outpatient Care were monitoring agents, and only $8.6 \%$ were farmers. At that time, women were the majority of patients (53\%), mainly among monitoring agents (67.5\%), whereas in the current study, men predominated. The highest percentage of women assisted between 2003 and 2005 is mainly due to the profile of the monitoring agents in that period (67.5\% women), compared with the investigated in the present study (42.6\% women).

The low level of education of farmers assisted in the Outpatient Care in the present study, considering that almost half have only elementary education (up to 8 years of schooling), was also reported in the previous study ${ }^{(11)}$ and in field studies with farmworkers in Brazil ${ }^{(12-15)}$. This profile reflects the education of the Brazilian people: about $41.4 \%$ of individuals aged 25 years or more had 1 to 7 years of study in the period of 2007 and $2015^{(16)}$. In the Federal District, $38.7 \%$ of the population studied up to the elementary school in $2011^{(10)}$. The low educational level of workers can affect the reading and understanding of pesticides' labels and the guidelines of safe use, and increase the chance of poisoning ${ }^{(17)}$. The educational profile of the farmworkers in Brazil is similar to that found in other developing countries, such as China ${ }^{(18)}$, but quite different from the farmers in the United States, in which $90 \%$ of the 57,310 evaluated workers had at least 12 years of schooling ${ }^{(19)}$.

On the other hand, more than $80 \%$ of the environmental monitoring agents assisted in the Outpatient Care had at least high school education, minimum level required for the public service exam for the occupation. These agents are workers of public health campaigns of the State Health Office of the Federal District for the actions of control to disease vector and endemic agents of the National Health Foundation.

The exposure to sanitizers was only by the cleaning assistants/ one-day cleaner, and includes products containing sodium hypochlorite. This was also the main agent involved in poisonings with illegal sanitizers in Maringá, Paraná State ${ }^{(20)}$. Occupational poisoning by household sanitizers accounted for $6.6 \%$ of occupational poisoning recorded by SINITOX between 2009 and $2013^{(3)}$. In a study conducted by Correa ${ }^{(21)}$, in order to evaluate the exposure of 159 domestic workers to sanitizers, $39.0 \%$ reported health alterations during their handling and $16.1 \%$ were effectively removed because of disease related to exposure to these products.

The use of PPE is aimed at minimizing risk and reducing the occurrence of poisoning and other occupational accidents, and Chapter V of the Brazilian Labor Code (CLT, Law 6514 of December of 1977) stipulates that such equipment must be provided by the employer to the worker for free. This study shows that $81.7 \%$ of the workers assisted did not use any PPE during the occupational activity, and non-compliance reached $73 \%$ among the monitoring agents. A most critical situation was observed in a previous 
study conducted in the outpatient care, where 147 of 157 agents received the PPE, but $93.9 \%$ of them reported not use them, mainly for being uncomfortable ${ }^{(11)}$. The use of PPE in the countryside for farmworkers is more necessary in small proprieties, where farmers use low technology to apply pesticides, such as coastal applicators and tractors with opened booth ${ }^{(13-14)}$. Different rates of adherence to this equipment have been reported in studies conducted in the country. High adherence (78.6\%) was observed among the 370 workers exposed to pesticides, attended in 2006 and 2007 in the Toxicology Outpatient Care of the Hospital das Clínicas of UNICAMP(22). In the Federal District, $44.4 \%$ of the farmers from the Federal District reported to use full PPE( ${ }^{(13)}$, while more than $80 \%$ of farmers in Mato Grosso do Sul stated that they did not use PPE ${ }^{(14)}$, although they knew about this equipment and considered that they should use them, but they mentioned the discomfort and their own "sloppiness" in not using them ${ }^{(23)}$. The non-regular use of PPE was also identified by $70 \%$ of farmworkers evaluated in Nova Friburgo, Rio de Janeiro State ${ }^{(24)}, 40 \%$ in Paraná State ${ }^{(25)}$, but only by $10 \%$ of the family fruit farmers in Rio Grande do Sul State ${ }^{(26)}$. It is likely that warmer temperatures, found in some regions of the country, may detract from the use of PPE in workers, due to the discomfort they cause, mainly related to the use of waterproof boots and visor, mask, shirt, pant and apron.

All the assessed workers exposed to pesticides reported exposure to multiple compounds of this group, even if only a part of them knew how to identify these compounds. Simultaneous exposure to multiple chemicals is common in the countryside and has been reported by other authors in Brazil ${ }^{(14,22,24)}$ and in other countries ${ }^{(27)}$, being related to the increased incidence of various diseases, including cancer ${ }^{(27)}$.

The evaluation of a group of workers exposed and potentially poisoned, relies on the tripod: history of exposure, clinical assessment and laboratory diagnosis. For example, a worker who applied pesticides without using PPE and had intense headache, contact dermatitis, pruritus and eye redness and dry cough, but presented normal cholinesterase test was considered as poisoned based on clinic. In another case, a worker with repeated exposure to pesticides reported mild headache and with decreased $\mathrm{BChE}$ was considered poisoned based on the laboratory test.

In this study, more than half of the workers were considered poisoned according to clinical and laboratory criteria. Among workers exposed to pesticides, this percentage was 56\%, higher than the one found in the previous study with outpatient care data from 2003 to 2005 (22.9\%), based on similar criteria, but involving predominantly environmental monitoring agents ${ }^{(11)}$. In the study with outpatient care data of farmers exposed to pesticides, for at least one year and performed by Figueiredo et al. ${ }^{(22)}, 21 \%$ were diagnosed as having a probable health effect (workers whose physical and/or laboratorial tests presented alterations), much smaller than that found in the present study for their population (65.5\%).

The organophosphate insecticides were involved in most of the cases with identified agents, mainly the tempos, present in 35 cases of poisoning of environmental monitoring agents. This larvicide was the only one used in combating the vectors in the Federal District until November of 2011, when it was replaced by diflubenzuron (6 cases of poisoning), later replaced by pyriproxyfen, considered safe by the World Health Organization ${ }^{(28)}$. The organophosphate methamidophos, involved in 8 cases of poisoning, had their registration canceled in Brazil in 2011, when the majority of its products was classified as extremely or highly toxic ${ }^{(29)}$.

Of the 47 poisoned with organophosphate insecticides identified in the study, $71.7 \%$ did not report the use of PPE and $47.8 \%$ reported at least one neurological symptom, mainly headache. None of the workers poisoned with pyrethroids presented dermatological effects, but 6 presented neurological effects, and only three were wearing any PPE while working. Exposure to pyrethroids is common, and mainly causes allergic reactions, but severe occupational poisoning is rare ${ }^{(30)}$.

Glyphosate has been involved in 22 cases, mainly with farmworkers, with 17 confirmed poisonings. Glyphosate, the most widely used herbicide in Brazil, (31), was recently classified as a probable carcinogen to humans (Group 2A) ${ }^{(32)}$, which has led many countries to reassess its use, including Brazil(33). Only 4 of the workers poisoned by this product was using any PPE during the working, and 6 presented different neurological symptoms.

Most workers exposed to pesticides and subjected to BChE test had results altered, in accordance with the established criteria. The evaluation of farmworkers assisted in the outpatient care of the Hospital das Clínicas of the UNICAMP, were found laboratory changes in $29.7 \%$ of the patients, of whom $37.2 \%$ showed change in cholinesterase test, being $78 \%$ with change in $\mathrm{BChE}^{(22)}$. Pasiani et al. ${ }^{(13)}$ showed that BChE levels found among the 64 workers of the family farming in the Federal District and their relatives were significantly lower during the period of exposure in the countryside compared to the non-exposure period and the control group. However, only one of the 60 farmers assessed had enzyme inhibition greater than $50 \%$, which can indicate disease and be associated with an effect or a dysfunction of the system, according to NR-7 ${ }^{(34)}$. None of the 173 truck farmer from Paraná State assessed by Nerilo et al. ${ }^{(25)}$ had BChE activity inhibited by more than $50 \%$ in relation to the control.

In addition, most other studies assessed the levels of erythrocyte cholinesterase (acetylcholinesterase, $\mathrm{AChE})^{(13,22,25)}$, biological indicator of effect of organophosphates and carbamates more specific than the BChE. The AChE dosage is also foreseen in the Brazilian legislation ${ }^{(34)}$, and should be included in the future evaluations of workers assisted by the outpatient care to help to identify cases of poisoning.

The industrial chemicals were the second group of compounds involved in occupational exposures, of which $80 \%$ were considered poisoning and included workers from garage and petrol stations, mainly by exposure to solvents and lead. These products are neurotoxic ${ }^{(2)}$, which was proved by the large number of poisoned workers reporting neurological symptoms.

The economic activity of the Federal District is mainly consisted of services, and the industrial and agriculture and livestock farming contribute with only $6.5 \%$ e $0.3 \%$, respectively ${ }^{(10)}$. This profile clearly shows that although it contributes little to the region's economy, agriculture and livestock farming is a risky activity in relation to chemicals poisoning.

The National Health Policy for Workers ${ }^{(9)}$ stipulates that "CERESTs shall be entitled to direct monitoring actions, only in a complementary or supplementary manner in situations where 
the municipality does not have the technical and operational conditions, or for those defined as of greater complexity". According to RENAST, there are currently 220 CERESTs established in Brazil, regional and state ${ }^{(35)}$, and few studies report the activities of these centers. SILVA et al. ${ }^{(36)}$ evaluated the data of 218 medical records of patients assisted from January to September of 2004 at the CEREST of Jequié, Bahia State, mainly involved in industrial activity. Spagnuolo et al. ${ }^{(37)}$ assessed the cases of exposure to biological materials assisted at the CEREST of Londrina, Paraná State.

\section{Study limitations}

The first limitation of the study is related to the number of visits made in the outpatient care, which may not reflect the number of employees at risk due to exposure to chemicals in the Federal District. A lot of them do not look for the public health network and when they do, the symptoms reported may not be identified by the professional as related to occupational activity, and the workers are not forwarded to the outpatient care of the CEREST. Additionally, the worker, in most cases, does not know the name of the chemical involved in the exposure, which can complicate the diagnosis of poisoning.

Therefore, it is important to point out that the study reflects only the profile of the workers exposed to chemicals in the CEREST of the Federal District in this period, and probably underestimates the number of events that occur in the Federal District.

Another limitation refers to the incompleteness of data in the medical record, mostly regarding laboratory tests. Additionally, the BChE activity test currently used by CEREST of the Federal District and its interpretation should be reassessed, as they do not reflect the scientific knowledge of the subject, as it does not consider preoccupational exposure and does not include the AChE, which is provided for in Brazilian legislation.
The limitations pointed out are directly related to the limitations of the entire health system in the region, including Basic Care, Family Health and health monitoring practice.

\section{Contributions to Nursing, Health or Public Policy}

This was the first study conducted in the country that assesses cases of occupational exposure to different chemical agents assisted at outpatient care of a reference center for workers' health. Their results are important to identify and establish primary care actions that can improve care, prevent poisoning, and improve the quality of life of this population.

\section{CONCLUSION}

The profile of workers assisted in the Outpatient Care for Occupational Toxicology of the CEREST in the period of the study was men, mainly aged from 30 to 39 years, that did not use PPE. The majority of workers was diagnosed as poisoned, mainly by pesticides, applied by farmers or environmental monitoring agents, and industrial chemicals, related or not to metals. Organophosphate insecticides were the main pesticides involved in poisoning, and the majority of workers who did the enzymatic dosing showed decreased $\mathrm{BChE}$.

Preventive actions with workers are necessary to reduce the occurrence of poisoning by chemical products, as well as the full integration of this population into the National Health Policy for Workers. In addition, it is necessary to reassess and improve the outpatient care procedures of the entire public health network of the Federal District regarding the care of exposed workers, to make it easier to identify poisoning and to provide proper treatment to this population.

\section{REFERENCES}

1. Agency for Toxic Substances and Disease Registry (ATSDR). The priority list of hazardous substances that will be the candidates for toxicological profiles [Internet]. Atlanta (GA): ATSDR; 2015 [cited 2017 Oct 17]. Available from: https://www.atsdr.cdc.gov/spl/

2. Centers for Disease Control and Prevention (US). Fourth report on human exposure to environmental chemicals. Atlanta (GA): CDC; 2009. [cited 2017 Oct 17] Available from: https://www.cdc.gov/eDentrexposurereport/

3. SINITOX: Sistema Nacional de Informações Tóxico-Farmacológicas [Internet]. Brasília: Fiocruz; 1999 [cited 2017 Oct 17]. Casos registrados de intoxicação humana por agente tóxico e circunstância [Table 6]. Available from: http://sinitox.icict.fiocruz.br/dados-nacionais.

4. Magalhães AFA. Avaliação das intoxicações exógenas no Distrito Federal no período de 2009 a 2013 [Thesis on the Internet]. Brasília: Universidade de Brasília, Programa de Pós-graduação em Ciências da Saúde, 2017 [cited 2017 Oct 17]. 153 p. Available from: http://www. toxicologia.unb.br/admin/ckeditor/kcfinder/upload/files/Tese\%20final\%20Andrea\%20Amoras-completa.pdf.

5. Sousa FN, Santana VS. Mortality from work-related accidents among agricultural workers in Brazil, 2000-2010. Cad Saúde Pública [Internet]. 2016 [cited 2017 Oct 17]; 32(4): e00071914. Available from: http://www.scielo.br/pdf/csp/v32n4/1678-4464-csp-32-04-e00071914.pdf.

6. Caldas ED. Pesticide Poisoning in Brazil. Ref Modul Earth Syst Environ Sci [Internet]. 2016 [cited 2018 Sep 1]; Available from: https://www. sciencedirect.com/science/article/pii/B9780124095489102829?via\%3Dihub doi: 10.1016/B978-0-12-409548-9.10282-9

7. Malaspina FG, Michael LZ, Priscila CB. Epidemiologic profile of the pesticides intoxication in Brazil, in the period 1995 to 2010. Cad Saúde Coletiva [Internet] 2011 [cited 2017 Oct 17]; 19(4):425-34. Available from: http://www.cadernos.iesc.ufrj.br/cadernos/images/csc/2011_4/ artigos/csc_v19n4_425-434.pdf. Portuguese.

8. IBGE: Instituto Brasileiro de Geografia e Estatística [Internet]. Brasília: IBGE; 2017. Indicadores de Desenvolvimento Sustentável: Tabela 772 Comercialização de agrotóxicos e afins, área plantada das principais culturas e comercialização por área plantada. 2014 [cited 2017 Oct 17] Available from: https://sidra.ibge.gov.br/tabela/772. 
9. Ministério da Saúde (BR). Gabinete do Ministro. Portaria no 1823, de 23 de agosto de 2012. Institui a Política Nacional de Saúde do Trabalhador e da Trabalhadora [Internet]. Diário Oficial da União: República Federativa do Brasil. 2012 [cited 2017 Oct 17];Aug 24; Seção 1: [about 2 screens]. Available from: http://bvsms.saude.gov.br/bvs/saudelegis/gm/2012/prt1823_23_08_2012.html

10. Companhia de Planejamento do Distrito Federal (Codeplan), Secretaria de Estado do Planejamento e Orçamento do DF (SEPLAN). Distrito Federal em síntese: informações socioeconômicas e geográficas [Internet]. Brasília: Codeplan, SEPLAN, 2012 [cited 2017 Oct 17] 78 p. Available from: http://www.codeplan.df.gov.br/images/CODEPLAN/PDF/pesquisa_socioeconomica/df_em_sintese/Sintese_de_ Informacoes_Socioeconomicas_2012.pdf

11. Magalhães AFA. Avaliação Clínico-Ocupacional de Trabalhadores assistidos no Ambulatório de Toxicologia Ocupacional-Brasília [Dissertation on the Internet]. Brasília: Universidade de Brasília, Programa de Pós-graduação em Ciências da Saúde; 2005 [cited 2017 Oct 17$].$ 107 p. Available from: http://www.toxicologia.unb.br/admin/ckeditor/kcfinder/upload/files/disserta\%C3\%A7\%C3\%A30\%20andrea.pdf.

12. Soares WL, Freitas EA V, Moro S. [Rural work and risk factors associated with pesticide use in Minas Gerais, Brazil]. Cad Saúde Pública [Internet]. 2003 [cited 2017 Oct 17]; 19(4):1117-27. Available from: http://www.scielo.br/pdf/csp/v19n4/16860.pdf.

13. Pasiani JO, Torres P, Silva JRCV, Diniz BZ, Caldas ED. Knowledge, attitudes, practices and biomonitoring of farmers and residents exposed to pesticides in Brazil. Int J Environ Res Public Health [Internet]. 2012 [cited 2017 Jun 11]; 9(9):3051-68. Available from: http://www.mdpi. com/1660-4601/9/9/3051.

14. Recena MCP, Caldas ED, Pires DX, Pontes ERJC. Pesticides exposure in Culturama, Brasil - Knowledge, attitudes, and practices. Environ Res [Internet]. 2006 [cited 2017 Oct 17];102(2):230-36. Available from: https://doi.org/10.1016/j.envres.2006.01.007.

15. Campos É, dos Santos Pinto da Silva V, Sarpa Campos de Mello M, Barros Otero U. Exposure to pesticides and mental disorders in a rural population of Southern Brazil. Neurotoxicology [Internet]. 2016 [cited 2017 Oct 17]; 56:7-16. Available from: https://doi.org/10.1016/j. neuro.2016.06.002.

16. IBGE: (Instituto Brasileiro de Geografia e Estatística [Internet]. Rio de Janeiro: IBGE; c2018. Distribuição das pessoas de 25 anos ou mais de idade, por grupos de anos de estudo - Brasil - 2007/2015; [cited 2017 Oct 17]; [about 1 screen]. Available from: https://brasilemsintese.ibge. gov.br/educacao/anos-de-estudo.html

17. Waichman AV, Eveb E, Nina NCS. Do farmers understand the information displayed on pesticide product labels? A key question to reduce pesticides exposure and risk of poisoning in the Brazilian Amazon. Crop Prot [Internet]. 2007 [cited 2017 Oct 17];26(4):576-83. Available from: https://doi.org/10.1016/j.cropro.2006.05.011.

18. Zhang X, Zhao W, Jing R, Wheeler K, Smith GA, Stallones L, Xiang H. Work-related pesticide poisoning among farmers in two villages of Southern China: a cross-sectional survey. BMC Publ Health [Internet]. 2011 [cited 2017 Oct 17];11:429. Available from: https://www.ncbi.nlm. nih.gov/pmc/articles/PMC3126745/pdf/1471-2458-11-429.pdf.

19. Bonner MR, Beane Freeman LE, Hoppin JA, Koutros S, Sandler DP, Lynch CF, Hines CJ, Thomas K, Blair A, Alavanja MC. Occupational exposure to pesticides and the incidence of lung cancer in the agricultural health study. Environ Health Perspect [Internet]. 2017 [cited 2017 Oct 17];125(4):544-51. Available from: https://ehp.niehs.nih.gov/wp-content/uploads/advpub/2016/7/EHP456.acco.pdf.

20. Santos JAT, Seleghim MR, Marangoni SR, Gonçalves AM, Ballani TSL, Oliveira MLF. Severity of poisoning by illegal sanitizing. Texto Context Enferm [Internet]. 2011 [cited 2017 Oct 17]; 20:247-54. Available from: http://www.scielo.br/pdf/tce/v20nspe/v20nspea31.pdf.

21. Corrêa LML. Saneantes domissanitários e saúde: um estudo sobre a exposição de empregadas domésticas [Dissertation on the Internet]. Rio de Janeiro: Universidade Federal do Rio de Janeiro; 2005. [cited 2017 Oct 17]; 94 p. Available from: http://www.posgraduacao.iesc.ufrj.br/ media/tese/1370441571.pdf.

22. Figueiredo GM, Trapé AZ, Alonzo HA. Multiple pesticide exposure and probable long-term health effects: transversal study in a sample of 370 rural workers of Campinas (SP - Brazil). Rev Bras Med Trab [Internet] 2011 [cited 2017 Oct 17];9(1):1-9. Available from: http://www. rbmt.org.br/details/93/pt-BR/exposicao-a-multiplos-agrotoxicos-e-provaveis-efeitos-a-longo-prazo-a-saude--estudo-transversal-emamostra-de-370-trabalhadores-rurais-de-campinas-sp Portuguese.

23. Recena MCP, Caldas ED. Risk perception, attitudes and practices on pesticide use among farmers of a city in Midwestern Brazil. Rev Saúde Pública [Internet] 2008 [cited 2017 Oct 17]; 42(2):294-301. Available from: http://www.scielo.br/pdf/rsp/v42n2/6777.pdf Portuguese

24. Araújo AJ, de Lima JS, Moreira JC, Jacob Sdo C, Soares Mde O, Monteiro MC, do Amaral AM, Kubota A, Meyer A, Cosenza CA, das Neves C, Markowitz S. Multiple exposure to pesticides and impacts on health: a cross-section study of 102 rural workers, Nova Friburgo, Rio de Janeiro State, Brazil. Ciênc Saude Coletiva [Internet]. 2007 [cited 2017 Oct 17]; 12(1):115-30. Available from: http://www.scielo.br/pdf/csc/ v12n1/11.pdf.

25. Nerilo SB, Martins FA, Nerilo LB, Salvadego VEC, Endo RY, Rocha GHO, Mossini SAG, Janeiro V, Nishiyama P, Machinski Jr. M. Pesticide use and cholinesterase inhibition in small-scale agricultural workers in southern Brazil. Braz J Pharm Sci [Internet]. 2014 [cited 2017 Oct 17];50(4):783-91. Available from: http://www.scielo.br/pdf/bjps/v50n4/1984-8250-bjps-50-04-00783.pdf.

26. Faria NMX, Rosa JAR, Facchini LA. [Poisoning by pesticides among family fruit farmers, Bento Gonçalves, Southern Brazil]. Cad Saúde Pública [Internet]. 2009 [cited 2017 Oct 17]; 43 (2):335-44. Available from: http://www.scielo.br/pdf/rsp/v43n2/en_7200.pdf Portuguese.

27. Kachuri L, Demers PA, Blair A, Spinelli JJ, Pahwa M, McLaughlin JR, Pahwa P, Dosman JA, Harris SA. Multiple pesticide exposures and the risk of multiple myeloma in Canadian men. Int J Cancer [Internet]. 2013 [cited 2017 Oct 17];133(8):1846-1858. Available from: http:// onlinelibrary.wiley.com/doi/10.1002/ijc.28191/epdf.

28. Organização Pan-Americana da Saúde. Nota de esclarecimento da Representação da OPAS/OMS no Brasil sobre o uso do larvicida 
Pyriproxyfen [Internet]. Brasília: PAHO/OMS; 2016 [cited 2017 Oct 17]. Available from: http://www.paho.org/bra/index.php?option=com_ content\&view=article\& id=5009:pyriproxyfen\&ltemid=816.

29. Ministério da Saúde (BR). Agência Nacional de Vigilância Sanitária. Resolução-RDC n 1, de 14 de janeiro de 2011. Regulamento técnico para o ingrediente ativo metamidofós em decorrência da reavaliação toxicológica [Internet]. Diário Oficial da União: República Federativa do Brasil; 2011 [cited 2017 Oct 17]. Jan 17 Seção1: 72p. Available from http://www.adapar.pr.gov.br/arquivos/File/GSV/Agrotoxicos/If_8_ resolucao_RDC_01_de_2011.pdf

30. Bradberry SM, Cage SA, Proudfoot AT, Vale JA. Poisoning due to pyrethroids. Toxicol Rev [Internet]. 2005 [cited 2017 Oct 17]; 24(2):93-106. Available from: https://link.springer.com/article/10.2165/00139709-200524020-00003.

31. Instituto Brasileiro do Meio Ambiente e dos Recursos Naturais Renováveis. Relatórios de Comercialização de Agrotóxicos. Boletim anual de produção, importação, exportação e vendas de agrotóxicos no Brasil, IBAMA. Os 10 ingredientes ativos mais vendidos [Internet]. 2017 [cited 2017 Oct 17]. Available from: http://www.ibama.gov.br/agrotoxicos/relatorios-de-comercializacao-de-agrotoxicos.

32. Guyton KZ, Loomis D, Grosse Y, El Ghissassi F, Benbrahim-Tallaa L, Guha N, Scoccianti C, Mattock H, Straif K. International Agency for Research on Cancer Monograph Working Group. Carcinogenicity of tetrachlorvinphos, parathion, malathion, diazinon, and glyphosate. Lancet Oncol [Internet]. 2015 [cited Oct 17] ;16(5):490-1. Available from: http://dx.doi.org/10.1016/S1470-2045(15)70134-8.

33. ANVISA: Agência Nacional de Vigilância Sanitária. [Internet]. Brasília: ANVISA; 2016. Regularização de produtos - agrotóxicos. [cited 2017 Oct 17]. Available from: http://portal.anvisa.gov.br/noticias/-/asset_publisher/FXrpx9qY7FbU/content/ anvisa-ira-reavaliar-glifosato-e-outros-quatro-agrotoxicos-utilizados-no-pais/219201/pop_up?_101_INSTANCE_.

34. Ministério do Trabalho (BR). Norma Regulamentadora № 07 - Programas de Controle Médico de Saúde Ocupacional (PCMSO). Diário Oficial da União: República Federativa do Brasil; 1978. Jun 08; Seção 1:21.

35. Rede Nacional de Atenção Integral à Saúde do Trabalhador (RENAST) [Internet]. Ministério da Saúde: Fiocruz; 2017 [cited 2017 Oct 17]. Available from: http://renastonline.ensp.fiocruz.br/cerests.

36. Silva ACC, Dias JS, Cardoso JP, Oliveira FKB. [Study of the demand assisted in a regional reference worker's health Center - CEREST/Jequié-BA. Rev Saúde Com [Internet]. 2006 [cited 2017 Oct 17]; 2(1):39-49. Available from: http://www.uesb.br/revista/rsc/v2/v2n1a5.pdf.

37. Spagnuolo RS, Baldo RCS, Guerrini IA. Epidemiological analysis of accidents with biological material reported to the Worker's Health Reference Center in Londrina-PR. Rev Bras Epidemiol [Internet]. 2008 [cited 2017 Oct 17]; 11(2):315-23. Available from: http://www.scielo. $\mathrm{br} / \mathrm{pdf} / \mathrm{rbepid} / \mathrm{v} 11 \mathrm{n} 2 / 13 . \mathrm{pdf}$ Portuguese. 